\title{
Notes
}

\section{Summary Processes and the Rule of Law: Expediting Death Penalty Cases in the Federal Courts}

\author{
Julia E. Boaz
}

On Friday, January 14, 1983, counsel for Thomas Barefoot, a prisoner condemned to death in Texas, filed a hastily prepared application to the Fifth Circuit Court of Appeals for a stay of execution pending appeal from the denial of his habeas corpus petition ${ }^{1}$ by the district court. ${ }^{2}$ Among other claims, Barefoot's petition challenged predictions of his

1. The writ of federal habeas corpus, "the best and only sufficient defense of personal freedom," Ex parte Yerger, 75 U.S. (8 Wall) 85, 95 (1868), is the principal exception to the general rule that state prisoners have no meaningful access to a federal forum for the litigation of federal constitutional claims. The writ authorizes lower federal courts to examine state court judgments collaterally. See generally L. YACKLE, POSTCONVICTION ReMedies $\S 14$, at 71-77 (1981). A state prisoner must first file a petition raising the constitutional errors that allegedly tainted the state processes leading to his or her conviction and sentence before "the Supreme Court, any justice thereof, the district courts and any circuit judge within their respective jurisdictions." 28 U.S.C. $\$ 2241$ (1982). In actuality the great weight of habeas practice is before the federal district courts, an arrangement that channels the bulk of federal examination of constitutional errors in state criminal processes into those courts. See generally P. BAtor, P. Mishkin, D. Shapiro \& H. Wechsler, HART \& WechSLeR's the Federal Courts and the Federal System 50-53 (2d ed. 1973) [hereinafter cited as Hart \& Wrchsler 2d ed.]; see also infra notes 73-79 and accompanying text. Upon the filing of a petition, the district court must, in a great many instances, hold an evidentiary hearing on the claims, if they are substantial. 28 U.S.C. $\S 2254$ (d) (1982). After disposition of the petition in the district court, either the petitioner or the state is entitled to appeal to the federal circuit court. Id. $\S 2253$.

2. On December 20,1982, a state trial court entered an order scheduling Barefoot's execution for January 25, 1983. Just one month before, a United States district court had denied Barefoot's petition for a writ of habeas corpus. Counsel moved in the Texas Court of Criminal Appeals on December 20, 1982 to stay Barefoot's execution. The Court of Criminal Appeals entered an order the next day denying a stay, but failed to notify counsel for Barefoot of its ruling until two weeks later. Counsel renewed his motion for a stay in the Court of Criminal Appeals on January 10, 1983, and that court denied the renewed motion the following day. Three days later, counsel filed the application for a stay of execution pending appeal in the Fifth Circuit. See Brief for Petitioner at 4-5, Barefoot v. Estelle, 463 U.S. 880 (1983). 
"long-term future dangerousness" that were offered at his sentencing trial by psychiatrists who had never examined him. ${ }^{3}$

Counsel's haste in this case was well-warranted: Though the district court had formally certified that Barefoot had probable cause to appeal," the state, unwilling to wait until filing or disposition of the appeal in the circuit court, petitioned the state trial court to set a date for Barefoot's execution. ${ }^{5}$ The imminence of that date-January 25th-triggered a hurried response from the Fifth Circuit.

Late Monday afternoon, January 17th, the court scheduled oral argument on the stay application for 9:00 a.m. on Wednesday; on Tuesday the state's motion in opposition to the stay was filed; on Wednesday a chaotic oral argument on the stay application ${ }^{6}$ was further confused by the state's

3. As a practical matter, the only issue to be decided by a sentencing jury under the Texas death penalty statute is the question whether "there is a probability that the defendant would commit criminal acts of violence that would constitute a continuing threat to society." TEX. CRIM. Proc. CodE ANN. $\$ 37.071(\mathrm{~b})(2)$ (Vernon 1981). The other two questions that the jury must answer in the affirmative in order to return a death sentence under Texas law, whether the defendant committed the crime deliberately and whether he acted in response to provocation, are answered in finding the defendant guilty of capital murder. See generally C. Black, Gapital Punishment: The Inevitability of CAPrice AND Mistake 111-35 (2d ed. 1981). Between 1974 and 1977 Texas prosecutors presented evidence supporting the future-dangerousness requirement in the form of psychiatric testimony-provided, in the overwhelming majority of Texas capital trials, by two Texas psychiatrists, James Grigson and John Holbrook. This testimony was derived from psychiatric examinations at which the defendant was not warned that what he said might be used to seek his execution. Eleven months prior to Barefoot's trial, however, this practice was declared in violation of a capital defendant's Fifth Amendment rights. In Barefoot's case, the prosecutor came up with what he termed "a pretty brilliant" idea for avoiding that holding-bypassing examination of Barefoot altogether and using expert opinion based only on a "hypothetical" picture of the defendant created by information given to the psychiatrists by the state. Record of Federal Habeas Corpus Hearing at 254, Barefoot, 463 U.S. 880.

Even in cases where the psychiatrist-witness has actually examined the defendant, the psychiatric community believes that predicting violent criminal acts in the indeterminate future stands, "generously analyzed-at the fringes of professional acceptability," and brings the doctor to the "brink of quackery." Dix, The Death Penalty, "Dangerousness," Psychiatric Testimony, and Professional Ethics, 5 AM. J. CRIM. L. 151, 172 (1977); see also Brief Amicus Curiae for the American Psychiatric Association, Barefoot, 463 U.S. 880 (psychiatric predictions of long-term future dangerousness are of fundamentally low reliability).

4. The habeas statutes provide that "the final order [of the federal district court] shall be subject to review, on appeal, by the court of appeals for the circuit where the proceeding is had," but that "[a]n appeal may not be taken to the court of appeals . . . unless the justice or judge who rendered the order or a circuit justice or judge issues a certificate of probable cause." 28 U.S.C. $\$ 2253$ (1982). Section 2251 authorizes "[a] justice or judge of the United States . . . before final judgment or after final judgment of discharge, or pending appeal, to stay any proceeding against the person detained .. . by or under the authority of any State for any matter involved in habeas corpus proceeding." Id. $\$ 2251$.

Section 2253 indicates that a prisoner, under any sentence, is entitled to appeal the denial of a petition for a writ of habeas corpus once he has obtained a certificate of probable cause. But carrying out a capital sentence prior to the disposition of a condemned prisoner's appeal will render his appeal moot. Thus the language of $\S 2253$ contemplates that a stay of execution will issue under $\S 2251$ whenever a condemned prisoner obtains a certificate of probable cause to appeal. Prior to 1982 the Fifth Circuit routinely granted stays under $\S 2251$ to condemned prisoners who had been granted a certificate of probable cause. See infra note 9.

5. See Brief for Petitioner at 27-28, Barefoot, 463 U.S. 880.

6. Id. 
submission of hundreds of pages from the habeas hearing that opposing counsel had never seen; Barefoot's counsel, lacking opportunity to brief the merits of his appeal, submitted the 1400-page record from Barefoot's state court trial; and one judge, nominated to the panel only hours earlier, had seen none of the papers in the case. ${ }^{8}$ On the following day, January 20th, the Fifth Circuit, applying a legal standard for staying a petitioner's execution that radically departed not only from its own prior approach, ${ }^{8}$ but also from that of every other circuit ${ }^{10}$ and the Supreme Court, ${ }^{11}$ issued a sixteen page opinion denying a stay. ${ }^{12}$

On January 21, counsel for Barefoot filed an emergency application for a stay of execution in the United States Supreme Court. In addition to raising the substantive issues presented below, counsel challenged the truncated procedures that had so hurriedly brought his client to the brink of execution. The Court, treating the application as a petition for certio-

7. See Brief Amicus Curiae for the NAACP Legal Defense and Educational Fund, Inc. at 14, 15, Barefoot, 463 U.S. 880.

8. Id. at 14.

9. In view of the irreparable harm to the petitioner if a stay is denied, the necessity of a stay when the condemned prisoner has obtained a certificate of probable cause to appeal would seem to be transparent. See supra note 4. But in its opinion in Barefoot's case, the Fifth Circuit adopted a new rule of judicial efficiency, treating a stay application in a death case no differently than stay applications in civil litigation. Barefoot v. Estelle, 697 F.2d 593, 595-96 (5th Cir. 1983). Thus, instead of automatically obtaining a stay once he had secured a certificate of probable cause, the petitioner would be required to make an affirmative showing of a likelihood of success on the merits. Id. at 595 . In so holding, the court relied upon precedent involving two stay applications in a ten-year old prisoners' rights class action that clearly would not have become moot regardless of the disposition of the stay applications-a case of rather dubious applicability to Barefoot's life or death situation. See Ruiz v. Estelle, 650 F.2d 555 (5th Gir. 1981).

10. Every other circuit to reach the question has automatically granted a capital petitioner a stay on his appeal from the denial of habeas corpus once he has obtained a certificate of probable cause to appeal. As the Fourth Circuit reasoned, "[i]n the very nature of proceedings on a motion for a stay of execution, the limited record coupled with the time constraints imposed by imminence of execution preclude any fine-tuned inquiry into the actual merits." Shaw v. Martin, 613 F.2d 487, 492 (4th Cir. 1980); see also Dobbert v. Strickland, 670 F.2d 938, 940 (11th Cir. 1982) ("Unless the execution of sentence is stayed in this case, the issues on appeal would become moot, and defendant would never have his day in this court on Constitutional issues."); Fouquette v. Bernard, 198 F.2d 96, 97 (9th Cir. 1952) ("Obviously, if there is probable cause for the appeal it would be a mockery of federal justice to execute [the petitioner] pending its consideration.").

11. Until Barefoot, the Supreme Court's own procedures for the issuance of stays in capital cases confirmed the circuits' judgment that the execution of a petitioner possessing a certificate of probable cause would be absurdly unfair. See, e.g., Lenhard v. Wolff, 443 U.S. 1306 (1979) (Rehnquist, J., granting stay pending further proceedings); Evans v. Bennett, 440 U.S. 1301, 1306 (1979) (Rehnquist, Circuit Justice) (noting the "obviously irreversible nature of the death penalty"); Gregg v. Georgia, 429 U.S. 1301 (1976) (Powell, Circuit Justice) (noting that "harm to petitioners obviously would be irreparable").

12. Barefoot v. Estelle, 697 F.2d 593 (5th Gir. 1983). The court of appeals decision was extraordinary in two principal respects. First, it is remarkable that the court was able to reach any opinion, given the fact that it had less than a day to study the voluminous record. In addition, the court had less than 24 hours to study - without the aid of full briefing and argument by the parties-the vast body of case law and psychiatric authority relevant to Barefoot's appeal. See supra note 3. Second, it is unclear whether the 16-page opinion constituted a ruling on the merits of Barefoot's claim-a question that confounded no less expert a body than the Supreme Court. See Barefoot, 463 U.S. at 889, 906-07. 
rari, granted certiorari, bringing these rushed proceedings to an abrupt-though temporary-halt. ${ }^{13}$

In Barefoot v. Estelle, the Supreme Court held that the federal circuit courts may provide death-sentenced petitioners with abbreviated versions of the ordinary processes afforded to all other habeas corpus litigants. ${ }^{14}$ The Court explained that capital petitioners may be afforded less time to plead their appeals than is given to noncapital petitioners because the death penalty, unlike a sentence of life imprisonment, prevents the state from exercising its right to carry out the sentence while the petitioner is litigating the appeal. ${ }^{15}$

Since Barefoot was decided in June 1983, forty-three persons have been involuntarily executed in the United States, a group that constitutes eighty-six percent of the executions carried out since the end in 1977 of the decade-long moratorium on capital punishment. ${ }^{16}$ For many of the persons executed, an order of the Supreme Court denying a stay of execution terminated judicial review. The Court's summary disposition of those appeals reveals an extraordinary division within the Court about the propriety of the procedures that now hurry a condemned person through the federal courts to execution.

In its decisions on stay applications, the majority of the Court has tended increasingly to characterize capital appeals as pretextual efforts to delay execution, attacking death-sentenced petitioners and their lawyers for their purported abuse of the federal courts. ${ }^{17}$ In response, dissenting justices have charged the majority with manipulating procedures in a manner that impugns the integrity of the federal courts and, indeed, of the Supreme Court itself. ${ }^{18}$

In this Note I will examine the debate underlying the Supreme Court's recent commitment-born of its decision in Barefoot-to expediting the normal deliberative processes for capital cases in the federal courts. I ar-

13. Barefoot was executed on October 30, 1984. NAACP Legal Defense \& Educational Fund, Inc., Death Row, U.S.A. at 3 (Aug. 1 1985) (unpublished compilation) (hereinafter cited as Death Row, U.S.A.].

14. Barefoot holds that the federal circuit courts can summarily decide a nonfrivolous federal claim in ruling on the capital defendant's motion for a stay of execution-absent, in other words, the full briefing and argument that ordinarily accompany a habeas corpus appeal. 463 U.S. at 894-95. As Justice Marshall, in dissent, pointed out, "an appeal that raises a substantial constitutional question is to be singled out for summary treatment solely because the State has announced its intention to execute the appellant before the ordinary appellate procedure has run its course." Id. at 913 (emphasis in original).

The Court also rejected Barefoot's substantive claims, holding, with three justices dissenting, that the use of psychiatric testimony to predict future-dangerousness for the purpose of securing a death sentence did not violate constitutional standards. Id. at 912-16. But cf. infra note 35.

15. Barefoot, 463 U.S. at 888.

16. Death Row, U.S.A., supra note 13.

17. See infra notes $38-41$ and accompanying text.

18. See infra notes $42-46$ and accompanying text. 
gue that the Court's commitment to speed in the disposition of capital appeals distorts the adjudicative processes that normally attend the administration of justice in the federal courts. First, the summary procedures place inordinate burdens on the ability of lawyers effectively to represent indigent death-sentenced clients in federal habeas corpus proceedings. Further, the new procedures strike at the very structure of the forum in which the post-conviction dispute takes place: Their summary character conflicts with a federal judiciary that, in habeas corpus proceedings, should limit and diffuse - rather than streamline-the states' power to impose the penalty of death. Finally, in abandoning procedural regularity, and the judicial deliberation and discourse that give voice to that regularity, the summary procedures threaten core principles of due process which are integral to the rule of law in our legal system.

\section{The New Death Penalty Jurisprudence}

In approving abbreviated procedures for capital cases in the federal courts, the Supreme Court inverted its own longstanding commitment to the principle that, because death is different from any other punishment in its severity and finality, capital cases require greater-not lesser-procedural safeguards. ${ }^{19}$ Indeed, the new expedited procedures emerge from the Court's attempts to extricate itself from the abundant procedural doctrine generated in its efforts, over the last ten years, to shape the states' death-sentencing processes to constitutional standards. ${ }^{20}$

In 1972, in Furman v. Georgia, ${ }^{21}$ the Supreme Court invalidated every capital punishment statute in the nation. Though Furman provoked nine separate opinions in the Court, ${ }^{22}$ its minimum ground was condemnation

19. The Supreme Court has long recognized that death is a unique sanction, constitutionally different from other lawful punishments, and hence deserving of special procedural protections. See, e.g., Beck v. Alabama, 447 U.S. 625, 637 (1980) ("As we have often stated, there is a significant constitutional difference between the death penalty and lesser punishments . . . ."); Lockett v. Ohio, 438 U.S. 586, 604 (1977) (plurality opinion) ("We are satisfied that this qualitative difference between death and other penalties calls for a greater degree of reliability when the death sentence is imposed.").

20. As one commentator has put it:

The federal courts face a great number of plausible claims of legal error because they have generated so much . . . doctrine under which [death] penalty trials must be conducted. If the [Supreme] Court can devise [special procedural rules for capital cases], it might be able to reduce the administrative cost of hearing these claims, while cheating on the intellectual cost of undoing the great doctrinal structure it has helped create.

Weisberg, Deregulating Death, 1983 Sup. CT. REv. 305, 346.

21. 408 U.S. 238 (1972) (plurality opinion).

22. Furman was decided just one year after McGautha v. California, 402 U.S. 183 (1971), in which the Court held that the Fourteenth Amendment does not prohibit unguided discretion in capital sentencing. Furman, relying on Eighth Amendment analysis, disapproved such absolute discretion, but its "ruling" was so splintered by its many opinions that it has generated great inconsistency in the subsequent capital punishment law. See Gillers, Deciding Who Dies, 129 U. PA. L. Rev. 1, 11 (1982). 
of the randomness by which those selected to die are separated from those eligible in law to die. ${ }^{23}$ In 1976, the Court upheld the capital punishment statutes in Georgia, ${ }^{24}$ Florida ${ }^{25}$ and Texas, ${ }^{26}$ but continued its often uncertain and tortuous attempts to elaborate constitutional limitations on the states' administration of the death penalty. ${ }^{27}$ The Court's numerous and varied holdings established that the unique constitutional status of the death penalty requires strict adherence to the principle of fairness and reliability in the procedures that inform death sentencing. ${ }^{28}$

In three cases decided within weeks of Barefoot, however, the Court signaled a radical shift away from that decade-long effort. ${ }^{29}$ Those cases permit the sentencer-whether judge or jury-virtually untrammeled discretion in the determination of who is selected to die. ${ }^{30}$ This reversal in the approach to capital sentencing ${ }^{31}$ reveals a Court uneasy at the thoroughgoing condemnation of state criminal processes implicit in its own prolific doctrine-making. ${ }^{32}$

23. See C. BLACK, supra note 3 , at 20-21.

24. Gregg v. Georgia, 428 U.S. 153 (1976) (plurality opinion).

25. Proffitt v. Florida, 428 U.S. 242 (1976) (plurality opinion).

26. Jurek v. Texas, 428 U.S. 262 (1976) (plurality opinion).

27. In the 1976 cases, the Supreme Court upheld "guided discretion" capital punishment statutes which "minimize the risk of wholly arbitrary and capricious action" that was condemned in Furman. Gregg v. Georgia, 428 U.S. 153, 189 (1976) (plurality opinion). At the same time that it upheld these statutes, the Court invalidated a second response by several states to Furman-mandatory death sentences for capital murder. See, e.g., Woodson v. North Carolina, 428 U.S. 280 (1976) (plurality opinion). Thus, the constitutional death penalty statute falls somewhere in between a statute absolutely forbidding sentencer discretion and one absolutely allowing it. Yet the Court has appeared conflicted about where that midpoint is. See Gillers, supra note 22, at 23-31.

28. Because of the unique difference between execution and all other criminal sanctions, for example, the Supreme Court "has gone to extraordinary measures to ensure that the prisoner sentenced to be executed is afforded process that will guarantee, as much as is humanly possible, that the sentence was not imposed out of whim, passion, prejudice or mistake." Eddings v. Oklahoma, 455 U.S. 104, 118 (1982) (O'Connor, J., concurring) (Constitution requires that states allow sentencing authority in capital cases to consider any mitigating factor offered by defense); see also Bullington v. Missouri, 451 U.S. 430 (1981) (right to preclude double jeopardy where the defendant has won a "life sentence" verdict); Estelle v. Smith, 451 U.S. 454 (1981) (Fifth Amendment privilege against self-incrimination applies to evidence used at penalty phase of capital trial); Green v. Georgia, 442 U.S. 95 (1979) (per curiam) (capital defendant has compulsory process right to introduce favorable penalty phase testimony regardless of constraints of state evidence law).

29. Zant v. Stephens, 462 U.S. 862 (1983); California v. Ramos, 463 U.S. 992 (1983); Barclay v. Florida, 463 U.S. 939 (1983).

30. For a brief analysis of the dissolution of Furman's directives in the 1982 Term cases, see The Supreme Court, 1982 Term, 97 HARv. L. Rev. 71, 118-127 (1983).

31. As one commentator has put it, the Court's abrupt reduction of the law of the penalty trial to "almost a bare aesthetic exhortation that the states just do something-anything-to give the death penalty a legal appearance" reveals "the art of legal doctrine-making in a state of nervous breakdown." Weisberg, supra note 20 , at 306 .

32. The import of the Supreme Court's voluminous articulation of limitations on the states' power to impose death, together with the remarkable rate of reversals of death sentences in both the Supreme Court and the lower federal courts from 1976 to 1982, see infra text accompanying notes $48-51$, is that state court processes-in a manner not piecemeal but systematic-are, in this area, subconstitutional. Such a conclusion cannot but create enormous tensions in the relationship between state institutions and the federal courts. As amicus curiae for the states in one of the 1982 Term capital cases 
An increasing number of death-sentenced petitioners are now entering the appellate stages of the federal habeas process ${ }^{33}$ challenging the deathsentencing scheme by means of the very blueprint provided in the Court's own capital punishment law. ${ }^{34}$ Like many other capital petitioners entering the federal courts, Thomas Barefoot's appeal raised complex questions of reliability and fairness in the imposition of his death sentence implicating many of the Supreme Court's prior holdings in capital cases. ${ }^{35}$ His case was extraordinary only in the Fifth Circuit's willingness to adjudicate his appeal with breakneck speed because the state succeeded in setting a date for his execution. In Barefoot, the Supreme Court stripped these chaotic and pressured procedures of their extraordinariness, finding instead that they comport with the state's interest in swiftly exercising its "right" to carry out the sentence of death.

\section{Manipulation of Procedures: By Death Penalty Lawyers OR BY THE COURT?}

\section{A. The Debate in the Supreme Court}

In Barefoot, the Court's only rationale for authorizing deference to the command of the state in seeking execution is suggested in what Justice Marshall, dissenting, termed a "cryptic" allusion to the principle that the "administration of justice ought not to be interfered with on pure pretexts." ${ }^{36}$ Though oblique in Barefoot, the Court's suggestion that capital appeals may be pretextual to an extent that justifies the adoption of summary procedures constitutes a recurring theme in the Court's recent dispo-

asserted, "the persistent, ex cathedra interference of an all-knowing, over-arching Federal judiciary which constantly expands and tinkers with the procedural protections afforded to capital defendants interferes with the right of the States to protect their citizens. . . " Brief Amicus Curiae for the Washington Legal Foundation at 31, Zant v. Stephens, 462 U.S. 862 (1983). See also Brief Amici Curiae for the States of Alabama, California, Florida, Missouri, North Carolina, South Carolina and Utah, Stephens.

33. The majority concedes this fact in Barefoot, 463 U.S. at 892.

34. See supra text accompanying note 19-20.

35. Barefoot's claim implicated the core theme in the Supreme Court's post-1976 decisions in death cases. To allow an expert well-known for his readiness to aid the state in obtaining its death penalties to urge the "future dangerousness" of a man whom he has never examined, thus supplying the answer to the sole question that the jury must answer in deciding whether that man will live or die, cannot but violate the reliability upon which the Supreme Court once insisted in capital cases. See, e.g., Bullington v. Missouri, 451 U.S. 430, 446 (1981) ("[I]n a capital sentencing proceeding it is the State, not the defendant, that should bear almost the entire risk of error.") (quoting Addington v. Texas, 441 U.S. 418,424 (1979)).

36. Barefoot, 463 U.S. at 914 (Marshall, J. dissenting) (quoting Lambert v. Barrett, 159 U.S. 660,662 (1895)).

Commentators have been at something of a loss to explain the reasoning that underlies Barefoot. See, e.g., Special Project, Capital Punishment in 1984: Abandoning the Pursuit of Fairmess and Consistency, 69 Cornell L. REv. 1129, 1209 (1984) ("The Court in Barefoot failed to give any reasons for its approval of expedited procedures in capital cases, thus making the decision difficult to analyze."). 
sition of those appeals. ${ }^{37}$ Members of the Court have repeatedly expressed impatience and irritation with execution delays, ${ }^{38}$ an attitude suggesting illegitimate manipulation of procedures on the part of death penalty lawyers. ${ }^{39}$ For example, Justice Rehnquist, dissenting from the denial of certiorari in Coleman v. Balkcom, ${ }^{40}$ complained that the "arcane niceties" of capital sentencing review pursued by lawyers representing deathsentenced prisoners amount to a "mockery of our criminal justice system" by providing such prisoners with "too many bites of the apple."41

In Coleman, Justice Stevens, in sharp response, accused Justice Rehnquist of seeking to grant certiorari in every capital case coming from the state courts in order to speed up executions in the United States. ${ }^{42}$ That attack constitutes but one in an increasing number of statements by individual Justices charging the majority with the "truly . . . perverse"43 use of the new procedures in the federal courts to "dramatically expedite the normal deliberative processes to clear the way for impending execution."14 In the words of the dissenters, this "frenzied rush to execution . . . has

37. See, e.g., Stephens v. Kemp, 464 U.S. 1027, 1032 (1983) (Powell, J., dissenting from grant of stay) ("Once again . . . a typically 'Iast minute' flurry of activity is resulting in additional delay of the imposition of a sentence imposed decades ago."); Gray v. Lucas, 463 U.S. 1237, 1240 (1983) (Burger, C.J., concurring in denial of certiorari and denial of application for stay) ("This case illustrates a recent pattern of calculated efforts to frustrate valid judgments after painstaking judicial review over a number of years .....").

38. Justice Powell, for example, has made his impatience a subject of a speech to the Eleventh Circuit Conference. Justice Powell's Remarks to the Eleventh Circuit Conference in Savannah, Georgia (May 8-10, 1983). The Association of the Bar of the City of New York, perhaps the most prestigious local bar association in the country, has responded by denouncing the Court's new penchant-whether on or off the bench-for derogating death penalty lawyers. Committee on Civil Rights of the Bar Ass'n of the City of New York, The Death Penalty, 1984, 39 REc. A.B. CrTY N.Y. 419 (1984).

39. See, e.g., Sullivan v. Wainwright, 464 U.S. 109, 112 (1983) (Burger, C.J., concurring in denial of stay). In Sullivan, Chief Justice Burger accused death penalty lawyers of turning "the administration of justice into a sporting contest," and announced his opinion that ten years on death row is harsher punishment than execution. This view could not have provided consolation to the condemned man who, throughout his long wait on death row, had repeatedly urged, in maintaining his innocence, that an accomplice who testified against him and who received, as a result, a lesser sentence, had falsely accused him. On the day Sullivan died in Florida's electric chair, the accomplice was free on parole. Wicker, No Further Appeal, N.Y. Times, Dec. 2, 1983, at A27, col. 4. The prevalence in capital cases of such gross sentencing disparties-often manipulated by the prosecution-is startling. See, e.g., Bentele, The Death Penalty in Georgia: Still Arbitrary, 62 WASH. U.L.Q. $573,575-89$ (1985) (chronicling sentencing disparities in Georgia system).

40. 451 U.S. 949,958 (1981) (Rehnquist, J:, dissenting from denial of certiorari).

41. Id. at 957 .

42. Id. at 950 (Stevens, J., concurring in denial of certiorari); see also California v. Ramos, 463 U.S. 992, 1029-31 (1983) (Stevens, J., dissenting) (criticizing Justices for granting certiorari solely to speed imposition of death penalty in California.).

43. Barefoot, 463 U.S. at 913 (Marshall, J., dissenting).

44. Autry v. McKaskle, 104 S. Ct. 1458, 1459 (1984) (Marshall, J., dissenting from denial of certiorari) ("Unfortunately, this case is not an aberration but is part of a pattern of recent decisions in each of which the Court has shown an unseemly desire to bring litigation in a capital case to a fast and irrevocable end."). 
become a common, if Kafkaesque, feature of the Court's capital cases, an effect representative of "result-orientation carried to its most cynical extreme."

\section{B. Death Penalty Litigation and the "Frivolous" Appeal}

The Supreme Court has voiced its suggestion that capital appeals are pretextual interferences with the federal judicial machinery only in vague terms. ${ }^{47}$ As set forth below, this assumption disregards evidence indicating that few capital appeals are legally frivolous. Further, it ignores the professional obligations of the death penalty bar, increasing the burdens of lawyers already overwhelmed by the financial, professional and emotional costs of representing death-sentenced clients.

\section{Likelihood that a Capital Appeal Will Present Substantial Issues}

Between 1976, when the Supreme Gourt restored the death penalty in Gregg v. Georgia, ${ }^{48}$ and the time of Barefoot's appeal in 1983, the federal courts of appeals had decided $73.2 \%$ of the capital cases adjudicated on the merits in favor of the death-sentenced individual. ${ }^{40}$ This number stands out starkly against the rates of success for appeals in noncapital cases. For example, during the twelve month period ending in June, 1981, shortly before Barefoot began its course through the federal courts, federal criminal defendants in noncapital cases who appealed succeeded at an overall rate of only $6.5 \% .^{80}$ It is not easy to reconcile this remarkable rate of reversals of death sentences with the Barefoot Court's suggestion that the expedited procedures respond to a wave of frivolous capital appeals. ${ }^{51}$

45. Dobbert v. Wainwright, 105 S. Ct. 34, 41 (1984) (Marshall, J., dissenting from denial of stay of execution).

46. Stephens v. Kemp, 105 S. Ct. 530, 540 (1984) (Brennan, J., dissenting from denial of stay of execution); see also Woodard v. Hutchins, 104 S. Ct. 752, 755 (1984) (Brennan, J., dissenting from vacation of stay) ("When a life is at stake, the process that produces this result [five members of the Court quickly vacating stay of execution granted by circuit court pending its disposition of merits of appeal] is surely insensitive, if not ghoulish."); id. (Stevens \& White, JJ., dissenting from vacation of stay) (criticizing the majority's "opaque order" to vacate stay as deviation from "orderly procedures"); Wainwright v. Adams, 104 S. Ct. 2183, 2184 (1984) (Marshall, J., dissenting from vacation of stay) ("The haste and confusion surrounding this decision is degrading to our role as judges. We have simply not had sufficient time with which to consider responsibly the issues posed by this case.").

47. See supra notes $36-41$ and accompanying text.

48. 428 U.S. 153 (1976) (plurality opinion).

49. See Brief Amicus Curiae for the NAACP Legal Defense and Educational Fund, Inc., app. E, at $1 \mathrm{~b}-1 \mathrm{~b}$, Barefoot, 463 U.S. 880 . This high rate of reversals occurred despite the fact that the death sentences had already been upheld on direct and collateral appeal in the state courts.

50. See Admin. Office of the U.S. Courts, 1981 AnnUal Report 97; see also Greenberg, Capital Punishment as a System, 91 YALE L.J. 908, 917-18 (1982) (comparing high rate of reversals in death penalty cases with the low rates of success on appeal in noncapital cases in various states).

51. In the post-Barefoot age, this point is somewhat roundabout, for the 1982 Term cases recognize that our legal system cannot tolerate both a death penalty that is constitutional in the best of all possible worlds and a rate of reversals of death sentences in the federal courts that constantly and 
Even assuming that Barefoot responds to a real problem of meritless capital appeals, the rushed procedures it sanctions weed out unworthy cases only at a high risk of mistake. It is precisely the problem with the new procedures, of course, that they provide no measured or sensible system for ascertaining which cases should not proceed on the "fast track" to execution. ${ }^{.22}$

A "legally frivolous" issue, the Court has indicated, is one that is either clearly foreclosed by a squarely controlling recent holding of the Supreme Court or lacking any factual basis whatsoever in the record of the case. ${ }^{\mathrm{bs}}$ Because the ambiguity accompanying most constitutional litigation has typically been heightened in the Court's death penalty law, ${ }^{54}$ this definition of the legally frivolous appeal encompasses, even after Barefoot, very few capital cases. It would thus seem reasonable that a fair method of administering the death penalty would allow each condemned person the opportunity to have his constitutional claims determined once on the merits by the federal judiciary - the very method dictated by the federal habeas corpus statutes. Such a method rests on the judgment that the state does not suffer unduly if the rare frivolous appeal lasts several months instead of being disposed of in a matter of days or hours. Yet this judgment seems sound: If the state's interest in death penalty cases translates into a desire to carry out executions ordered by state courts, the burgeoning number of such cases entering the final stages of the federal habeas corpus process assures that that interest would have been protected without help from the new procedures. To execute sooner rather than later increases the rate of executions only by including in the number executed those persons whose cases were tainted with constitutional errors that went uncorrected because the summary procedures limited the scope or quality of federal review.

Barefoot's clipped procedures, however, subordinate the great risk of error that inevitably attends the assessment on emergency stay applica-

dramatically serves to remind that this world is certainly flawed. Accordingly those cases all but announce that the soaring rate of reversals will not be tolerated in the federal system. See supra notes 29-32 and accompanying text.

52. By contrast, the congressional requirement that a capital petitioner obtain a certificate of probable cause to appeal before being granted a stay of execution does provide such a system. See supra note 4. In 1908, acting to prevent frivolous appeals from burdening the federal courts and the state criminal justice system, Congress amended the habeas statute, which had required an automatic stay of proceedings against a petitioner pending his appeal, to require that a death-sentenced person first obtain a certificate of probable cause before appealing from the denial of habeas corpus in the district court. The Habeas Corpus Act, ch. 76, 35 Stat. 40 (1908), (codified as amended at 28 U.S.C. $\S 2253$ (1982)). Yet Congress left noticeably unchanged its requirement that a capital defendant obtain a stay of execution pending the resolution of his appeal once he secures a certificate. Id. Barefoot thus tampers with a question long settled by congressional action.

53. Barefoot, 463 U.S. at 894,912 n.9.

54. See supra notes $21-28$ and accompanying text. 


\section{Expediting Death Penalty Cases}

tions of meritorious issues in the vast majority of cases to the state's interest in clearing the way for execution in the case of the rare frivolous appeal.

\section{Professional Obligations and Performance of the Death-Penalty Bar}

As a matter of professional ethics, a lawyer representing a deathsentenced person, like any other lawyer, must work aggressively for her client's ends, regardless of whether political or social factors surrounding the dispute make that obligation uncomfortable. ${ }^{55}$ Yet death-penalty lawyers may also have special ethical obligations. When litigation of an issue creates costs, to society or to a client, that outweigh possible benefits, a lawyer representing a non-capital client may exercise a professional judgment dictating restraint. ${ }^{56}$ But the interests of both society and client may demand that this analysis not apply when the client stands to lose his life in losing the dispute.

Courts have forcefully expressed the need for more stringent requirements for sentencing and review in capital punishment cases. ${ }^{57}$ This need requires special diligence and alertness on the part of death penalty lawyers. ${ }^{58}$ Indeed, the Supreme Court has created special procedural safeguards designed to enhance the adversarial capacity of the defense for a person on trial for his life. ${ }^{59}$ These heightened adversarial protections re-

55. Canon 7 of the ABA Model Code of Professional Responsibility requires that a lawyer represent her client "zealously within the bounds of the law." MODEL CODE of Professional RESPONSIBILITY, Canon 7 (1979). Disciplinary Rule 7-101 forbids a lawyer from intentionally failing "to seek the lawful objectives of his client through reasonably available means." Id. at DR 7-101(A) (1). Though "a lawyer is not justified in asserting a position in litigation which is frivolous," id., EG 7-4, she may "urge any permissible construction of the law favorable to her client," including a position "supportable by a good faith argument for an extension, modification, or reversal of the law," regardless of "[her] professional opinion as to the likelihood that the construction will ultimately prevail." Id. at EC 7-4.

56. In the exercise of her professional judgment, a lawyer may, "where permissible" (this phrase is not defined), refrain from asserting a right or position of her client. Id. at DR 7-101(B)(1).

57. See supra notes $19,28$.

58. In reality, however, the typical defendant on trial for his life cannot afford to hire a wellqualified lawyer, or to compensate one well enough to encourage truly "zealous" representation. Professor Charles Black has written persuasively about the "warping effects of race and poverty" on the capital defendant's ability to secure competent representation. C. BLACK, supra note 3, at 94-102.

59. Since 1976, the Supreme Court has imposed the constitutional due process model of the guilt trial on the penalty phase of the capital trial. See supra note 28 . This development recognizes that capital sentencing demands greater opportunity for the defense to present and confront all evidence relevant to the imposition of the penalty. Thus, in Gardner v. Florida, 430 U.S. 349 (1977), the Court struck down a Florida procedure that allowed the penalty trial judge to review a presentence report, prepared by the state, which the defense never saw. Similarly, in Eddings v. Oklahoma, 455 U.S. 104 (1982), and Lockett v. Ohio, 438 U.S. 586 (1978) (plurality opinion), the Court expanded the defense's capacity to present any and all evidence relevant to the particular defendant that could tip the scales toward life, banning state procedures that more narrowly restrict the scope of the capital sentencing decision. 
flect the recognition that, because reliability in sentencing is an issue of constitutional magnitude in the capital context, ${ }^{60}$ a lawyer must bring to the attention of the court and the state all errors that have infected the death-sentencing process in her client's case.

It is difficult to envision how an attorney for a death-sentenced person can provide even minimally adequate representation under the emergency review conditions sanctioned by Barefoot, much less the more conscientious lawyering demanded by the Court in its past exhortations on the constitutional importance of reliability in capital sentencing. For some of the attorneys representing death row inmates, particularly the many who are unpaid and work in small-town practices with little or no support services, ${ }^{61}$ the professional and emotional costs of representation under the expedited schedules will no doubt prove insurmountable. The withdrawal of these lawyers from the death penalty bar will strike a debilitating blow to a system of post-conviction representation already plagued by such a critical shortage of lawyers that it may well be, in the words of the American Bar Association, "poised for collapse."

On the other hand, some attorneys may be able to withstand the disruption to paying practices and personal lives caused by their frenetic efforts to ward off a rapidly approaching execution date in order to secure a more measured consideration of their client's constitutional claims. Unfamiliar with federal litigation, however, many of these lawyers may not properly pursue their cases according to appellate rules or they may fail to make their way through the intricacies of capital punishment or constitutional law; $; 3$ or, however conscientious, they may not be able to fly hun-

60. See supra note 28 and accompanying text.

61. See generally Brief Amicus Curiae for the NAACP Legal Defense and Educational Fund, Inc., at 31-32, Barefoot, 463 U.S. 880.

62. ABA Planning System, Program Activity Proposal on ABA Post-Conviction Death Penalty Project (Nov. 21, 1983) at 4-5. The ABA concluded that its nationwide project to coordinate private counsel to represent indigent death-row inmates in post-conviction proceedings could easily fail to remedy the existing lack of "minimum legal representation in post-conviction proceedings." Id. As the number of capital cases entering the federal habeas process increases, the ability of organizations experienced in the representation of death row inmates, such as the NAACP Legal Defense Fund, to provide emergency assistance diminishes rapidly. According to a recent report of the New York Bar Association:

Given the finality of the punishment [of death] and the unprecedented number of people now facing it, the nation's return to the death penalty raises a serious crisis of due process. . . . The shortage of volunteer attorneys and the ever-growing death row population raises the spectre of pro se defendants lacking adequate skill to present the issues in habeas proceedings, or worse, executions of defendants unable ever to marshall such an effort.

The Death Penalty, 1984, 39 REC. A.B. CIrY N.Y. 425 (1984). The situation has also provoked activity on the bench: Chief Judge John Godbold of the Eleventh Circuit urged an audience at a meeting of the Florida Bar to volunteer to provide desperately needed post-conviction representation for death-sentenced inmates. Address by Chief Judge John Godbold, Annual Convention of the Florida Bar Association (Sept. 29, 1984).

63. The chaotic, eleventh-hour nature of the proceedings can cause even experienced counsel to falter. In Brooks v. Estelle, 697 F.2d 586 (5th Cir. 1982) (per curiam), counsel overlooked a critical 
dreds of miles for oral argument at a moment's notice or prepare stay applications overnight. ${ }^{\text {s4 }}$

Such a picture is, in certain respects, a cheerful one: It does not include the spectre of the all too human lawyer who is unable to heed the hard demand of the profession - that commitment to loyal and vigorous defense work supersede the influences of peer pressure, community sentiment, or concerns for professional reputation. ${ }^{65}$ For the local lawyer representing a capital client in an atmosphere of outrage, fear, or racial hostility, that demand has always been a grueling one. But in a legal climate that is increasingly poisoned by the Supreme Court's own denigration of capital appeals, and the petitioners and lawyers who bring them, ${ }^{66}$ only the super-human lawyer may be able to resist the temptation to approach her client and her task with scorn, distaste or resignation. In continuing to cast opprobrium on these lawyers' efforts, the Supreme Court further cripples the quality and scope of assistance rendered to these most needy of criminal defendants.

\section{Summary Processes and the Structure of the Federal JUDICIARY}

The new, expedited procedures not only strike at the capacity of lawyers to provide minimally effective assistance to defendants under a sentence of death. Even more fundamentally, they distort the very nature of the federal forum in which the habeas corpus dispute in capital cases takes place. Dissenting justices have decried these distortions, voicing their harshest criticism of the expedited procedures in those cases that reveal

precedent in support of Brooks' principal argument on his motion for a stay in the court of appeals. Counsel relied primarily on a Ninth Circuit precedent, though a Fifth Circuit precedent, not discovered until after Brooks' execution, squarely supported the proposition. Because the Fifth Circuit strictly adheres to the rule that only the en banc court may overrule the prior decision of a panel, a citation to the case should have caused the Brooks panel to stay his execution. Interview with Joel Berger, Assistant Counsel at NAACP Legal Defense and Educational Fund, Inc., in New York Gity (Dec. 14, 1984).

64. The emergency review conditions shaped by the new procedures exacerbate the blunders of all too human lawyers, causing them to take on a fatal significance. In the case of James Hutchins, members of a local firm serving as Hutchins' counsel failed to challenge the jury selection process in the case in his first habeas corpus petition. The issue, the subject of a favorable ruling before a federal district judge of the same circuit and currently pending before the Supreme Court, was later raised in Hutchins' second petition. Hutchins' counsel attributed their oversight to the flurry of activity that surrounded the first petition. Petitioners' Response to Respondents' Motion to Dismiss, Woodard v. Hutchins, 464 U.S. 377 (1984); see also infra note 90 (describing jury selection process in Hutchins' case). And by the time of the second petition, in March, 1984, the issue was obscured by the fact that the case was moving through the courts at the blistering pace required by the imminent execution date. See Woodard v. Hutchins, 464 U.S. 377 (1984). Hutchins was executed on March 16, 1984.

65. For a sobering account of the indecencies, large and small, that result when lawyers for a condemned person fail to act responsibly and loyally, see Babcock, Gary Gilmore's Lawyers, 32 STAN. L. REv. 865 (1980).

66. See supra notes $36-46$ and accompanying text. 
the Court's heightening of its supervision over the lower federal courts. This greater control is illegitimate, these justices urge, precisely because it is aimed at abbreviating habeas review in all capital cases. ${ }^{67}$ The impropriety of the Court's expanding supervision over stay applications emerges with particular clarity when those actions are viewed within the context of traditionally nonhierarchical aspects of the federal judiciary. In this section I will discuss the manner in which the Supreme Court's recent actions in capital cases threaten those institutional traits.

\section{A. Nonhierarchical Nature of the Federal Judiciary}

Though the concept of a government limited by multiple centers of authority, each of which "check and balance" one another, typically describes the relationship between the different branches of government at the same level, it also informs the relationship between state and federal institutions in our federal system. ${ }^{68}$ The interplay between the state and federal court systems may be seen as an instance of this vertical allocation of authority ${ }^{69}$ Never primarily tribunals possessing exclusive subject matter jurisdiction, the federal courts have the power to hear cases most of which could have been adjudicated in at least one of the state systems. ${ }^{70}$ This structural pattern of concurrency of jurisdiction countenances indeterminacy of judicial solutions, ${ }^{71}$ an approach more broadly reflected in the American adherence to the principle of limited and diffused governmental authority. ${ }^{72}$

67. See, e.g., Woodard v. Hutchins, 464 U.S. 377, 381 (1984) (Brennan, J., dissenting from vacation of stay) (criticizing Court's "indefensible-and unexplained" rush to vacate stay granted by court of appeals before 6:00 p.m. execution date, thus preempting circuit's ruling on merits of habeas petition); id. (Stevens \& White, J.J., dissenting); Wainwright v. Adams, 104 S. Ct. 2183, 2183-84 (1984) (Marshall, J., dissenting from vacation of stay) (criticizing Court's decision to vacate stay without benefit of briefing or argument, when stay was granted after careful determination by circuit court).

68. The American adherence to the principle of "checks and balances" has led to the diffusion of authority not only among government powerholders at the same level, but also along a vertical axis. This vertical allocation of authority creates a complex mosaic of local power centers, subordinate to the federal government, but possessing substantial autonomous powers. Damaska, Structures of Authority and Comparative Criminal Procedure, 84 YALE L. J. 480, 532-39 (1975); see G. WoOD, The Creation of the american Republic 151, 602-06 (1969); The Federalist Nos. 10, 47, 51 (J. Madison).

69. For example, Madison urged that a system of lower federal courts could correct the "local prejudices" of state courts. See H. Hart \& H. Wechsler, The Federal Courts aNd the FedERAL System 17 (1953) (quoting $1 \mathrm{M}$. FarRand, The Records of THE Federal Convention of 1787 (1937)); Cover, The Uses of Jurisdictional Redundancy: Interest, Ideology, and Innovation, 22 WM. \& MARY L. REv. 639, 661, 665 (1981).

70. See HART \& Wechsler, $2 \mathrm{~d}$ ed., supra note 1 , at $418-38$.

71. For a more sophisticated exploration of the implications of this jurisdictional overlapping of state and federal court systems, see Cover, supra note 69.

72. The separation of powers principle may be conceived as calling less for a separation of legislative, judicial and executive functions than for the establishment of interdependent power centers which check and balance one another, limiting authority so as to heed the political imperative that great concentrations of power be prevented at all costs. See Damaska, supra note 68, at 532-33 \& n.133; J. 
The relationship between the Supreme Court and the lower federal courts reflects similar values. As a practical matter, the Supreme Court is precluded from articulating a national norm in the vast number of cases presented for its review. ${ }^{73}$ Yet even in those cases where a potential for a national uniform rule exists, our system often relies upon the multiple interpretive centers of the lower federal courts. ${ }^{74}$ The great measure of interpretive autonomy accorded to lower federal courts ${ }^{\mathbf{2 5}}$ expresses a preference for diversity of judicial decisionmaking, and for the multiple, individualized solutions that may accompany that diversity. ${ }^{26}$

The habeas corpus jurisdiction of the federal courts dramatically highlights these structural characteristics. ${ }^{77}$ In habeas corpus proceedings, the jurisdiction of the lower federal courts overlaps almost completely with that of the state, allowing a federal court to inquire into most claims that implicate the constitutionality of state court decisionmaking. ${ }^{78}$ The availability of extensive post-conviction review for state prisoners reflects the federal government's willingness to undercut a streamlined or mechanical administration of the law within a unitary court system in order to obtain greater enforcement of federal constitutional rights.

Locke, Two Treatises ON Government, Second Treatise, $\S 60$ at 173 (1960). Indeed, an arrangement in which state and lower federal courts enjoy a great deal of rulemaking autonomy is "healthier in a federal system." Cover, supra note 69 , at 673 .

73. See Hart \& Weschler, 2d ed., supra note 1, at 1600-13.

74. See Cover, supra note 69 , at 673 .

75. Lower federal court judges must defer to the words of the Supreme Court when those words apply to the case before them. Cooper v. Aaron, 358 U.S. 1 (1958). Yet until that rule applies, federal judges can-and do-act, in good faith, according to their own constitutional interpretations. See Cover \& Aleinikoff, Dialectical Federalism: Habeas Corpus and the Court, 86 Yale L. J. 1035, 1048-49 (1977).

76. The hierarchical nature of continental legal systems reflects the high premium placed on certainty of decisionmaking in continental political life, while the far less centralized Anglo-American systems express a preference, deeply rooted in the common law, for individualized justice. See generally J. Merryman, The Civil Law Tradition 48-55 (1969). Professor Mirjan Damaska argues that the continental model leads inexorably toward a centralization of authority and, hence, toward a rigorous hierarchical ordering of that authority. Damaska, supra note 68, at 483-509. AngloAmerican systems, by contrast, structure authority in the administration of justice-particularly criminal justice-as mildly as possible, accepting the ambiguities of overlapping spheres of rulemaking as part of their commitment to semi-autonomous official powers. Id. at 509-23.

77. Indeed, there may be no better illustration of a system that diffuses authority over both horizontal and vertical axes than the habeas corpus jurisdiction of the federal courts. The most striking characteristic of federal habeas corpus is that it authorizes the lower federal courts to examine state supreme court judgments collaterally. L. YACKLE, supra note 1, at 71-77. The use of habeas corpus as a means of restructuring or diffusing power between courts with overlapping jurisdiction dates from the sixteenth century, when the writ was used as a procedural device for enforcing the principles of the Magna Charta. Id. at 86.

78. Although the writ of habeas corpus originally contemplated only collateral attacks on convictions under invalid criminal statutes, and on sentences not allowed by law, legislative and judicial impatience with these restrictions from civil war time through the heyday of the Warren Court's constitutional innovations in criminal procedure gradually shaped the writ into a vehicle for the development and enforcement of constitutional principles. See L. YACKLE, supra note 1, at 84-101; Hart, The Supreme Court, 1958 Term-Forward: The Time Chart of the Justices, 73 HaRv. L. REv. 84, 106-07 (1959). 
This input of both a state and federal tribunal into the resolution of a single dispute on federal habeas corpus produces enormous complexity in the interplay between state and federal systems. ${ }^{79}$ Such complexity may create conflicts of rules and values that appear to threaten the relative autonomy of state systems, ${ }^{80}$ but it may also trigger an interjurisdictional dialogue between state and federal courts, providing a healthy support for our federal system. ${ }^{\mathbf{8 1}}$ Further, because the great weight of adjudication on habeas petitions rests with the lower federal courts, ${ }^{82}$ the Supreme Court traditionally has exercised little supervisory control over those courts' review, leaving ample opportunity for their meaningful participation in the processes that may lead to deprivation of life or liberty by the states. ${ }^{\mathbf{8 3}}$

These structural traits of the lower federal courts in habeas corpus proceedings have been of critical importance in the effort to elaborate constitutional limitations on the states' imposition of the death penalty. The Supreme Court's exhortations on the constitutional need for rationality and fairness in capital sentencing have, of course, spoken to the state courts. But because the Court's holdings have generated many constitutional challenges bearing on particularly sensitive aspects of state court processes-the claim, for example, that the death penalty is being administered in an arbitrary and discriminatory manner-the lower federal courts have provided an additional, more disinterested forum. ${ }^{84}$ Moreover,

79. As Justice Frankfurter, writing to defend habeas corpus in 1953 stated, "The complexities of our federalism and the workings of a scheme of government involving the interplay of two governments, one of which is subject to limitation enforceable by the other, are not to be escaped by simple, rigid rules which, by avoiding some abuses, generate others." Brown v. Allen, 344 U.S. 443, 498 (1953) (Frankfurter, J., concurring).

80. Some commentators have urged that an expansive federal habeas corpus remedy leads to needless and destructive interference with state affairs. See, e.g., Bator, Finality in Criminal Law and Federal Habeas Corpus for State Prisoners, 76 Harv. L. Rev. 441 (1963). The Burger Court has repeatedly defended federalism concerns in criminal proceedings at the expense of procedural protections afforded by habeas corpus. See, e.g., Rose v. Lundy, 455 U.S. 509 (1982) (requiring dismissal of habeas petitions containing claims not exhausted in state courts); Sumner v. Mata, 449 U.S. 539 (1981) (holding factual findings by state courts entitled to presumption of correctness on habeas corpus). As Barefoot demonstrates, the state's interest in the finality of its criminal judgments may supersede the unique finality of death.

81. See L. YACKLE, supra note 1, at 99-100; Brennan, Federal Habeas Corpus and State Prisoners: An Exercise in Federalism, 7 UTAH L. REv. 423, 442 (1961); Cover \& Aleinikoff, supra note 75, at 1046-52.

82. See L. YACKLE, supra note 1, at 84. This arrangement expresses "the choice of Congress how the superior authority of federal law should be asserted." Brown v. Allen, 344 U.S. 443, 510 (1953) (Frankfurter, J., concurring).

83. Cover \& Aleinikoff, supra note 75 , at 1048-52. This federal participation need not be seen as an instance of federal superintendence: The inevitable diversity created by multiple decisionmaking centers, each with regional, political and personal differences, has shaped a federal judiciary which does not speak-or even attempt, in the absence of controlling Supreme Court precedent, to speak-with one voice. See generally Cover \& Aleinikoff, supra note 75.

84. For example, in McCleskey v. Zant, 580 F. Supp. 338 (N.D. Ga. 1984), the capital petitioner filed a habeas corpus petition challenging the allegedly arbitrary and racially discriminatory application of Georgia's death penalty. The claim was based on a sophisticated statistical study which found strong and statistically significant evidence of racial disparities in the imposition of death sentences in 
because the Court's decisions have often spoken in uncertain terms, federal habeas corpus has provided the vehicle through which the lower federal courts have labored to transform those terms into actual rights with boundaries that can be reliably ascertained and applied in particular cases. ${ }^{85}$

\section{B. The Supreme Court's Expanding Supervisory Control Over Capital Appeals}

The Supreme Court's commitment to expediting the capital review process in the federal courts has eroded the structural safeguards against such expedition built into the federal judicial system. First, by abandoning the full briefing and argument necessary for a fair review of federal constitutional challenges to the state's imposition of the death penalty, Barefoot distorts the relationship between the state and lower federal courts on habeas corpus. Under Barefoot, a hurried mini-appeal on motion for stay of execution may be the only process afforded to the death-sentenced inmate who presents his properly preserved constitutional claims to a federal court for review on habeas corpus. ${ }^{86}$ Barefoot thus operates to constrict the overlap between the state and lower federal courts, undermining a key structural impediment to the state's impulse to propel a capital petitioner as rapidly as possible through post-conviction review to execution.

The Supreme Court's summary treatment of capital appeals has also transformed its relationship with the lower federal courts. Ordinarily the Court will overturn a court of appeals' decision to grant a stay of execution only when there has been a gross abuse of discretion by the lower

Georgia. McCleskey eventually lost his challenge, but only after a month-long evidentiary hearing in the federal district court and year-long deliberations on his appeal by the Eleventh Circuit sitting en banc. The circuit court conceded that racial disparities in capital sentencing did exist, but found that the petitioner had not demonstrated with sufficient "particularity" evidence of racial animus in his case. McCleskey v. Kemp, 753 F.2d 877, 885-900 (1985) (en banc). The state court, by contrast, had summarily dismissed MicCleskey's challenge. McCleskey v. State, 245 Ga. 108, 263 S.E.2d 146 (1979), cert. denied, 449 U.S. 891 (1980).

85. See supra notes 33-34 and accompanying text.

86. In some cases, the expedited procedures force the litigation to proceed with such momentum that even the most formidable obstacles cannot stop it. In one recent Florida case, the son of the man condemned to death for the killing of his daughter recanted testimony he gave at his father's trial years before that provided the sole evidence for the finding of premeditation. The father, Ernest Dobbert, raised this newly discovered evidence in his habeas petition, but his case was rushed through the lower federal courts in less than three days, with a dissenting circuit judge pleading that "there has not been enough time in which justiciably to decide this case." Dobbert v. Wainwright, 742 F.2d 1274, 1274 (11th Cir. 1984) (Clark, J., dissenting). Speeding to the Supreme Court, Dobbert asked the Court to pause just long enough to allow him to brief his appeal. Less than a day later, he was executed. No court had actually addressed the issue of whether the recantation testimony was credible evidence. Dobbert v. Wainwright, 105 S. Ct. 34 (1984). Justices Marshall and Brennan decried the federal court's treatment of the case, concluding that "[t]he 'right' of the state to speedy execution has now clearly eclipsed the right of an individual to considered treatment of a substantial claim that he has been sentenced to death for an offense he did not commit." Id. at 41 . 
court. ${ }^{87}$ The tolerance for a measure of interpretive autonomy accorded the federal appellate courts by this standard proscribes a strictly hierarchical administration of justice. ${ }^{88}$ In a number of capital appeals reaching the Supreme Court since Barefoot, however, the Court has exercised its extraordinary power to vacate a stay of execution, granted by a circuit court, in a one-sentence order, sometimes just hours before a scheduled execution. ${ }^{88}$ In another recent case, the Supreme Court rushed to vacate a stay of execution that had been granted by a Fourth Circuit judge for the express purpose of allowing the petitioner to live until an important and unresolved issue in his case-an issue now pending before the Supreme Court-could be decided more deliberately. ${ }^{80}$ The majority's disregard for the gross abuse of discretion standard in these cases, and for the institutional traits of the lower federal courts that it protects, reduces those courts to administrative arms of a Supreme Court dedicated to the speedy processing of capital appeals.

Ironically, the new procedures, though rushed, cannot remedy the administrative tangles purportedly characterizing the litigation of capital appeals in the federal courts. Federal judges, when faced with a capital appeal on habeas corpus, must often assess claims raising complex

87. See R. Stern \& E. Grossman, Supreme Court Practice 881-82 (1978).

88. While the existence of judicial discretion is abhorred in the more hierarchical continental legal systems, in the American legal system it is tolerated and even celebrated as an instance of the mild ordering of authority that attends a decentralized criminal justice system. See Damaska, supra note 68, at 509-23; see also K. DAvis, Discretionary Justice 216-17 (1969).

89. See, e.g., Wainwright v. Adams, 104 S. Ct. 2183 (1984); Stephens v. Kemp, 105 S. Ct. 530 (1984). In Adams, for example, the petitioner obtained a stay of execution on his second habeas petition from the circuit court after the court had "carefully explored whether or not the evidence of injustice warrants our consideration of this . . . writ." Adams v. Wainwright, 734 F.2d 511, 512 (11th Cir. 1984). Finding that the Supreme Court's vacation of the stay "committed an error with respect to process as well as result," dissenting Justice Marshall charged that "[h]ere . . . caution has been thrown to the winds with an impetuousness and arrogance that is truly astonishing." Adams, 104 S. Ct. at 2185 (Marshall, J., dissenting).

The summary vacation of the stay in Stephens' case was, if possible, even more egregious: In December, 1983, the Court stayed Stephens' execution pending the Eleventh Circuit's en banc resolution of the claim that Georgia's death penalty operated arbitrarily and in a discriminatory manner. Stephens v. Kemp, 464 U.S. 1027 (1983). In November, the discrimination issue still pending, the Court summarily reversed itself. The current state of affairs in the capital punishment arena shows that we are far from the point of concerning ourselves with the dignity of those whom we have sentenced to death. Yet what went through the mind of the condemned black man who learned that the highest court in the land had suddenly decided-without even one word of explanation-that his case need not await the determination of the discrimination issue by the Eleventh Circuit? Further, how did the Court's decision affect that very determination? The Eleventh Circuit subsequently decided that racial disparities in Georgia's system did not make out constitutional violations. See supra note 84 .

90. Woodard v. Hutchins, 464 U.S. 377, 383 (1984) (Marshall, J. dissenting). Hutchins urged that the "death-qualification" of his jury-the prosecution's exclusion at the guilt or innocence phase of his trial of prospective jurors who, though they could have been impartial in determining guilt or innocence, would have been unwilling to impose a death sentence in any subsequent penalty trial-violated his Sixth and Fourteenth Amendment rights. At the time of Hutchins' last appeal, a federal district judge in the Fourth Circuit had ruled favorably on the issue, and the issue was pending before the Supreme Court. On October 8, 1985, the Supreme Court granted certiorari to hear the issue in Lockhardt v. McCree, 106 S. Ct. 599 (1985). 
constitutional issues that require a thorough sifting of massive state court and federal district court records. Procedures that pace this difficult assessment according to emergency timetables dictated by rapidly approaching execution dates necessarily undermine the orderly administration of justice. ${ }^{91}$ It is difficult to picture a more chaotic adjudicatory process than one that forces a court of appeals to stand ever ready to thrust aside normal business in order to conduct overnight review of a habeas petition, with life or death hanging in the balance. ${ }^{92}$

\section{Summary Processes and the Rule of LaW}

The petty gambler or drug pusher who files a habeas corpus petition in a court of appeals possesses the basic procedural tools to challenge his conviction and sentence: He may obtain counsel who will not be hampered in her ability to represent him thoroughly and vigorously; he may see that his case is fully briefed and, if need be, argued orally before judges who have been duly assembled to hear him out. Not so the defendant who possesses a certificate of probable cause to appeal his death sentence. Such an effect does indeed ensure that "death is different." "93 It countenances a procedural irregularity in capital cases subversive of the "profound attitude of fairness . . . between the individual and government" which informs "due process" in American law and which underlies the minimum safeguards required by the habeas corpus statutes. ${ }^{95}$

91. Some circuit courts have attempted to bring a measure of order to these emergency adjudications by adopting special court rules for administering them. For example, when a capital appeal proceeding under an imminent execution date is denied in the federal district court, the Eleventh Circuit requires the clerk of the district court immediately to telephone the clerk of the circuit court and to forward copies of the papers filed. $11 \mathrm{TH}$ CIR. R. 30. But because these attempts at routinization do not address the source of the chaos-the inability of judges and courts to adjudicate complex issues at breathtaking speed-they seem bound to fail. As Justice Marshall has described, "[T]he Supreme Court has authorized the reviewing courts to put [the habeas] proceedings on fast forward .... When the process speeds up, the opportunity for deliberation, consideration and rebuttal vanishes. The proceedings collapse into each other and the appellate process loses its vitality." Justice Marshall, Remarks to the Second Circuit Conference in Hershey, Pa. (Sept. 6, 1985).

92. The case of Carl Songer, a Florida inmate, illustrates this disorder. Songer's appeal, proceeding under an execution date, was summarily rejected by the circuit court, Songer v. Wainwright, 755 F.2d 1394 (11th Cir. 1985), but when, just days before he was to die, the same court granted en banc relief to another habeas petitioner in a similar case, the court voted, once again en banc, to "recall the mandate"-an unprecedented move comparable to recalling the appeal-even though one judge confessed that it appeared the court had no jurisdiction to do so. Songer v. Wainwright, 756 F.2d 799 (11th Cir. 1985).

93. See supra note 28 and accompanying text.

94. Joint Anti-Fascist Refugee Comm. v. McGrath, 341 U.S. 123, 162 (1951) (Frankfurter, J., concurring). This "attitude" expresses a concept of procedural justice that recognizes the dignity of the person proceeded against by the government. See L. TRIBE, AmERICAN Constirutional LAw 501-04 (1978). Where the defendant may have committed a heinous crime, such an attitude may be most difficult to maintain. Yet, given that the impact of the state's coercive power in seeking death is so extreme, it may be of the greatest moment to a civilized system of justice.

95. See, e.g., 28 U.S.C. § 2243 (1982); see also Stephens v. Kemp, 105 S. Ct. 530, 538-39 (1984) (Brennan, J., dissenting from vacation of stay) (discussing basic due process guarantees for capital 
In elevating concerns for expedition in the processing of capital appeals above the measured deliberation and reasoned discourse ordinarily marking the due administration of justice in the federal courts, the new procedures strike at yet another due process value: the role of reason-giving in adjudication. ${ }^{96}$ The judicial articulation of principles and norms that attends dispute-resolution in the American legal system speaks to the values inherent in the concept of limited government, for such argument renders the decision, and the decision-making process, public and accountable. ${ }^{97}$

In capital punishment law, this judicial articulation gave voice to a decade-long experiment in the federal courts which, though ambiguous and uncertain, made visible the irrationality of the process by which a condemned person is brought to the brink of execution. At the time of Furman, the Supreme Court might have concluded that the administration of the death penalty, though arbitrary, could not be subjected to constitutional standards. But Furman condemned the states' administration of the death penalty in the language of federal imperatives, triggering more than ten years of judicial argument that dissected and displayed capital petitioners' claims that they were sentenced to death in violation of constitutional principles.

In its recent treatment of capital appeals, the Supreme Court abandons Furman's legacy, expressing instead a preference for the appearance of stability and order attendant upon the swift and final end of disputes. ${ }^{98}$

defendants required by habeas statutes). The Supreme Court has often analogized due process to the Magna Charta's guarantees against usurpations of official power. See, e.g., Murray's Lessee v. Hoboken Land \& Improvement Co., 59 U.S. (18 How.) 272, 276 (1856). The Magna Charta was also the mainspring of the writ of habeas corpus. See supra note 77.

96. See Cover, supra note 69, at 643-46 (arguing that adjudicatory action in American legal system requires that dispute resolution be accompanied by norm-articulation).

97. American democracy, and the political institutions that structure it, are based on the principle of visible, "legible" authority: Officials entrusted with power by the citizens may use discretion, but may not be permitted, absent compelling, countervailing interests, to obscure the manner of use. See R. SENNETT, AUTHORITY 165-90 (1980). The connection between political freedom and public reason-giving by those exercising power has exerted a powerful force in the common law. See K. LLEWELLYYN, JURISPRUDENCE 306 (1962).

98. This preference is illustrated in Justice Powell's dissent from the Court's decision to grant a stay of execution to a Georgia inmate who claimed that arbitrariness and racial discrimination pervaded the state's administration of its death penalty. Stephens v. Kemp, 104 S. Ct. 562 (1983). Though the identical claim was pending before the Eleventh Circuit in another case, Powell neglected to address this fact, announcing instead that the procedures for stay applications "undermine public confidence in courts and in the laws we are required to follow." Id. at 565 (Powell, J., dissenting). As Powell's vote, and those of the three justices who joined him, indicate, the value of that supposed public confidence may trump a condemned person's claim that he not be executed until a court of appeals determines whether a death-sentencing system is constitutional.

It is notable that Justice Powell's own votes on stay applications conflict with his ideal of stability in the administration of the laws. In Darden v. Wainwright, for example, the Court voted 5-4 to deny an emergency stay, with Justice Powell joining in the majority. Counsel for the petitioner immediately restyled the stay application as a petition for certiorari, which the four dissenting justices voted to grant. Justice Powell then voted to stay the petitioner's execution, explaining that his decision was influenced in part by the fact that the Justices were in various parts of the country. Darden v. Wain- 
The Court increasingly has articulated no more than the one word necessary to indicate whether a capital petitioner's stay application shall be upheld or denied, and thus whether the petitioner will live or die. When the Court has spoken, it often has registered irritation and impatience, ${ }^{99}$ but it rarely has ventured to justify its responses in a particular case.

Further, the Court's actions must be seen within the context of laws that are themselves fraught with uncertainty and failure. Indeed, the opinions of dissenting justices belie any appearance of order and certainty on the surface of the majority's death penalty jurisprudence, ${ }^{100}$ depicting a Court whose deliberative processes are drastically distorted by the frenzied, eleventh-hour nature of the proceedings. ${ }^{101}$ This picture of the Court's adjudication of capital appeals hardly comports with the symbolic function of an institution charged with upholding the image of continuity and justice in the law. ${ }^{102}$ More fundamentally, the Court's actions, in manifesting indifference to both the substance and appearance of justice in capital cases, ${ }^{103}$ conflict with the ideal of a neutral third-party deci-

wright, 106 S. Ct. 21, 22 (1985). Such a switch may have been, of course, the most prudent and deliberate response to the situation, but it is also the product of a judicial atmosphere that is far from stable or orderly.

99. The Court's abbreviated adjudication of capital appeals, together with the often scornful language, when it speaks at all, that accompanies its disposition of those appeals, creates the impression that the cases before the Court are in some manner clearly appropriate for the penalty of death. Upon closer inquiry, however, many of the cases that ended in execution over the last year are shot through with doubt. See, e.g., Maggio v. Williams, 464 U.S. 46, 56-65 (1983) (case ending in execution in which every tribunal-state and federal, district level and appellate-split on one or more of issues presented; in every case majority position prevailed by only one vote).

100. Yet the Court's actions have demonstrated its readiness to set aside even its ordinary court practices in order to clear the way for an impending execution. In Goode v. Wainwright, $104 \mathrm{~S}$. Ct. 378 (1983), for example, the Court reversed per curiam, without briefing or argument, the Eleventh Circuit's grant of sentencing relief on the ground that a subsequent decision of the Court invalidated the circuit's determination. Ordinarily, when an intervening decision of the Supreme Court may affect a lower court's decision, the Court grants the petition for certiorari, vacates the lower court judgment and remands for consideration in light of the intervening decision. Id. at 383-84 (Brennan, J., dissenting).

101. In Woodard v. Hutchins, 464 U.S. 377 (1984), for example, five members of the Supreme Court-without waiting for the Fourth Circuit to consider the merits of Hutchins' appeal-rushed to vacate a stay of execution, granted by the circuit, before the petitioner's death warrant expired at 6:00 p.m. that evening. Yet the Court had neither the circuit's decision, nor Hutchins' defense of the stay. It possessed only the state attorney general's three and a half page handwritten motion to vacate. Id. at 755 (Marshall, J., dissenting). "In all candor," Justice Marshall charged, "if there is an abuse of federal power in this matter, it is to be found in our own chambers." Id. at 756. See also Wainwright v. Booker, 106 S. Ct. 30, 31 (1985) (Marshall, J., dissenting) (Marshall, J., charging that Court had "moved with an 'impetuousness and arrogance that is truly astonishing" "in vacating stay granted by circuit to allow filing of petition for certiorari when Court had not seen such petition.)

102. It is not that the Court communicates no message at all, but that it has aligned its considerable interpretive force with the states as they exercise their "right" to carry out the ultimate sanction of death. Such actions, following as they do a decade of exhortations on the special constitutional status of death, drastically undercut the image of a Court whose "raison d'etre [is to] "preserve, protect and defend' principle." A. Bickel, The Least Dangerous Branch 188-89 (1962).

103. As an example of the Court's lack of concern that it maintain even the appearance of justice in capital cases, in Skillern v. Procunier, $105 \mathrm{~S}$. Ct. 945 (1985), the majority refused to stay the execution of a Texas prisoner who was one of eight named plaintiffs in a case that challenged the 
sionmaker, perhaps the most basic condition for judicial legitimacy in our legal system. ${ }^{104}$

\section{CONCLUSION}

In abbreviating a capital petitioner's ability to present habeas corpus challenges to the state court processes leading to his sentence, and a federal court's capacity to respond to them with care and deliberation, the expedited procedures approved in Barefoot subvert the basic components of adjudication in our courts. These truncated procedures, and the disregard for defense counsel that the Supreme Court has urged in implementing them, subvert the quality of defense assistance rendered to capital inmates. Further, they constrict the scope of the federal forum in which the dispute takes place, creating the unseemly arrangement in which the decision of the state to set an execution date forces the federal courts to provide the most hasty review to cases deserving of the most sober and deliberate reflection. Indeed, the procedures so distort federal review as to provide yet another instance of the arbitrariness and capriciousness in the administration of the death penalty that gave rise to the Court's landmark decision in Furman v. Georgia.

\footnotetext{
"agonizingly slow and painful death caused by lethal injection." Id. at 947 (Brennan, J., dissenting). The Court had granted certiorari to hear the case just weeks earlier. As Justice Brennan pointed out in dissent, "[ $t]$ he irony of the Court's . . . action will not be lost on the public, when we ultimately issue a decision to a plaintiff no longer able to receive it." Id.

104. See M. Shapiro, CourTs 1-64 (1981) (arguing that root concept of courts, and the basis of their political legitimacy in our society, inheres in existence of neutral third-party decisionmaker).
} 